\title{
Importance of phosphate pock application for sustaining agricultural production in Egypt
}

Farid Hellal ${ }^{1 *}$ (D), Saied El-Sayed ${ }^{1}$, Raafat Zewainy ${ }^{1}$ and Ahmad Amer ${ }^{1,2}$

\begin{abstract}
Background: Phosphorus is one of the essential nutrients required for plant growth. Although it is moderately available in nature, it is a deficient nutrient in most soils especially calcareous soils. Phosphate rock (PR) is considered the cheapest $P$ fertilizer. Phosphate rock sources may be of igneous or sedimentary origin.

Results: In Egypt, the natural phosphate rock is located in Sebaiya (Nile Valley), Safaga (Red Sea), and Abu Tartur (Western Desert). The higher the organic matter contents in soil, the better dissolution of the PR. Legumes are particularly suited for the use of PR. Biological solubilization of phosphate rock is more environmentally friendly than acidulation. Fungi are widely used as producers of organic acids, and particularly, some Aspergillus and Penicillium species have been directly introduced into the soil in order to solubilize the phosphate rock. Biological solubilization will make phosphorous available for plant use with minimum pollution to the environment. Phosphate rock inoculated with bacteria and Mycrrohizae proved to be a suitable approach to use PR for continuous crop production.
\end{abstract}

Conclusion: The amendments such as elemental sulphur, compost, organic manure, and plant waste could be applied to PR to improve crop cultivation under Egyptian soil conditions.

Keywords: PR sources, Sulphur, Cadmium, Aspergillus, Compost

\section{Introduction}

Phosphorus $(\mathrm{P})$ is an important plant nutrient after nitrogen. $\mathrm{P}$ availability is low in soils because of its fixation as insoluble phosphates of iron, aluminum, and calcium (especially in calcareous soil). Phosphorus deficiency is an important factor restricting plant growth, so chemical phosphatic fertilizers are widely used to get optimum yields. Soluble forms of phosphorus fertilizer used are easily precipitated as insoluble forms; this leads to the excessive and repeated application of $\mathrm{P}$ fertilizer to cropland. Despite its importance in plants growth and metabolism, phosphorus is the least accessible macronutrient and hence most frequently deficient nutrient in most agricultural soils because of its low availability and its poor recovery from applied fertilizers. The low availability of phosphorus is due to it readily forms insoluble

\footnotetext{
*Correspondence: hellalaf@yahoo.com

${ }^{1}$ Plant Nutrition Department, National Research Centre, El Buhouth St., Dokki, Cairo 126222, Egypt

Full list of author information is available at the end of the article
}

complexes with cation such as aluminum and iron under acidic soil condition and with calcium and magnesium under alkaline soil conditions whereas the poor phosphorus fertilizer recovery is due to the fact that the phosphorus applied in the form of fertilizers is mainly adsorbed by the soil and is not available for plants uptake (Cordell et al. 2011).

Phosphate rock application as fertilizer is known a long time ago. Phosphate rock is relatively slow to release soluble $\mathrm{P}$, yet its low price appears to be very attractive as a phosphate fertilizer in comparison to the industrial $\mathrm{P}$ fertilizers. In Egypt, Qena Governorate, Deshna, and surrounding villages, farmers are accustomed to the use of cretaceous phosphate rocks which they get from nearby hills as P fertilizer. Accordingly, it is worth to mention that (a) the Egyptian cultivated lands have $\mathrm{pH} 7.8-8.2$, and hence, they are not convenient to apply phosphate rock which needs acidic pH. (b) The subject needs detail studies including different types of cultivated soils (clay, sand, and calcareous ones); also, 
different types of phosphate rocks (Nile Valley, Red Sea, and Abu Tartur phosphate rocks) will be evaluated. The application of industrial fertilizers has many negative environmental impacts on cultivated soils. The applied fertilizers can accumulate in soils due to the fact that their quantities are much more than the amount in solution. Every cultivated soil has its own ecological equilibrium; the addition of industrial fertilizers will lead to many chemical and mineralogical changes which will disturb this ecological equilibrium (Elmaadawy et al. 2015).

\section{Phosphate rock sources}

Phosphatic rocks may be igneous as in Russia, Brazil, and South Africa; sedimentary in North Africa, Jordan, and Florida; or secondarily metamorphic in India. Apatite is observable in nearly all igneous rocks where it occurs in volumes ranging from 0.1 to $1.0 \%$. It is intimately associated with feldspars that are the continental crust-dominant mineral species and suggest, by mass balance, that they are the host of 50-90\% of crustal $\mathrm{P}_{2} \mathrm{O}_{5}$. The commonest and most extensive ores $(87 \%)$ are sedimentary and marine in origin (Van Kauwenbergh 2010). Phosphate rock (PR) is a globally accepted but imprecise term describing any naturally occurring geological material that contains one or more phosphate minerals suitable for commercial use. Five major types of phosphate sources in the world are as follows: marine phosphate deposits, igneous phosphate deposits, metamorphic deposits, biogenic deposits, and phosphate deposits as a result of weathering. Approximately $75 \%$ of the world's phosphate resources are from sedimentary, marine phosphate rock deposits, $15-20 \%$ from igneous and weathered deposits, and only $1-2 \%$ from biogenic resources and large bird and bat guano accumulations. Phosphate minerals in the primary environment include (1) fluorapatite $\left(\mathrm{Ca}_{10}\left(\mathrm{PO}_{4}\right)_{6} \mathrm{~F}_{2}\right)$, in igneous and metamorphic environments, as in carbonatites and mica pyroxenites; (2) hydroxyapatite $\left(\mathrm{Ca}_{10}\left(\mathrm{PO}_{4}\right)_{6}(\mathrm{OH})_{2}\right)$, in igneous and metamorphic environments and biogenic deposits, e.g., in bone deposits; (3) carbonate-hydroxy-apatites $\left(\mathrm{Ca}_{10}\left(\mathrm{PO}_{4}, \mathrm{CO}_{3}\right)_{6}(\mathrm{OH})_{2}\right)$, on islands and in caves, as part of birds and bat excrements, guano; (4) francolite $\left(\mathrm{Ca}_{10} \mathrm{NaMg}\left(\mathrm{PO}_{4}\right)_{6}\left(\mathrm{CO}_{3}\right) \mathrm{F}_{2}\right)$, carbonate-substituted apatite present in marine environments, and a much smaller extent in weathering environments for instance over carbonatites (Van Straaten 2002).

\section{World's phosphate rock reserves and resources}

Agriculture is the main user of phosphorus globally, accounting for between 80 and $90 \%$ of the total world demand (Reyes and Allsopp 2012). Phosphorus input is crucial for food production since all plants need an adequate supply of it for successful growth. Phosphorus deficiency will result in a reduction of crop yield. Phosphorus is essential for all living organisms. Agriculture is heavily dependent on mined phosphate rock, the only known primary source of phosphorus. Phosphorus reserves are only present in some regions of the world including Europe, India, and Australia being almost totally dependent on imports. The percentage of global production which was higher in China (39\%), the USA (16\%), Morocco and Western Sahara (15\%), and Russia (6\%). Jordan, Egypt, and Tunisia produce 3\% of the global production (Marjolein et al. 2012). The world annual phosphate production in 2012 is about 217 million tons, and the global reserves are about 67 billion tons (Elmaadawy et al. 2015). With the population increase, researchers estimate that the existing phosphate reserves may cover the world's requirements of phosphates for more than 100 years. Egypt has about 4\% of the world's phosphate reserves ( 2.78 billion tons) and produces about $3 \%$ of the world's phosphate production (about 6 million tons per year).

\section{Egypt phosphate rock reserves and resources}

The phosphate rocks in Egypt date back to the beginning of the last century, and their exploitation was initiated between 1908 and 1911 by foreign companies in regions along the Nile Valley and the Red Sea Coast and lately in Kharga Oases in the Western Desert. Since that time, phosphate mining and production have been surviving in the former two regions till the present. It was only in 1957 when the phosphate mining industry was nationalized that systematic studies on phosphate reserves and production were carried out. The phosphate rock occurrence in Egypt can be divided into three facies belts (Fig. 1). The economic importance is restricted and confined to the following localities: (1) along the Red Sea Coast from Safaga to Quseir land stretch, (2) the Nile Valley between Idfu and Qena and particularly near Sebaiya and El Mahammid, at Gabel Abu Had and WadiQena which have more economic deposits, (3) the Western Desert at Abu Tartur plateau between the Kharga and Dakhla oases. The phosphate rocks of this facies are associated with iron and/or sulphides. The phosphorite of the northern facies belt spreading from Bahariya Oasis to Sinai has no economic potential (Salib 2006).

The Egyptian reserves are $100 \mathrm{mmt}$ (HakamMahdy 2011). The EI Nasr Mining Company (ENMC) apparently controls all the reserves and resources of the Sabaiya area (east and west), the Eastern Desert, and the Red Sea coastal area. West Sabaiya reserves are indicated to have $24 \mathrm{mmt}$ of ore.

East Sabaiya reserves have a deposit of about $55 \mathrm{mmt}$ of ore. The ore is dry or wet screened depending on the area. The typical ore product ratio is 1.6. The content reserves of the West Sabaiya area are $15 \mathrm{mmt}$ and contain about $27 \% \mathrm{P}_{2} \mathrm{O}_{5}$. The reserves of concentrate for the East Sabaiya area are $34 \mathrm{mmt}$ and about $29-30 \%$ 


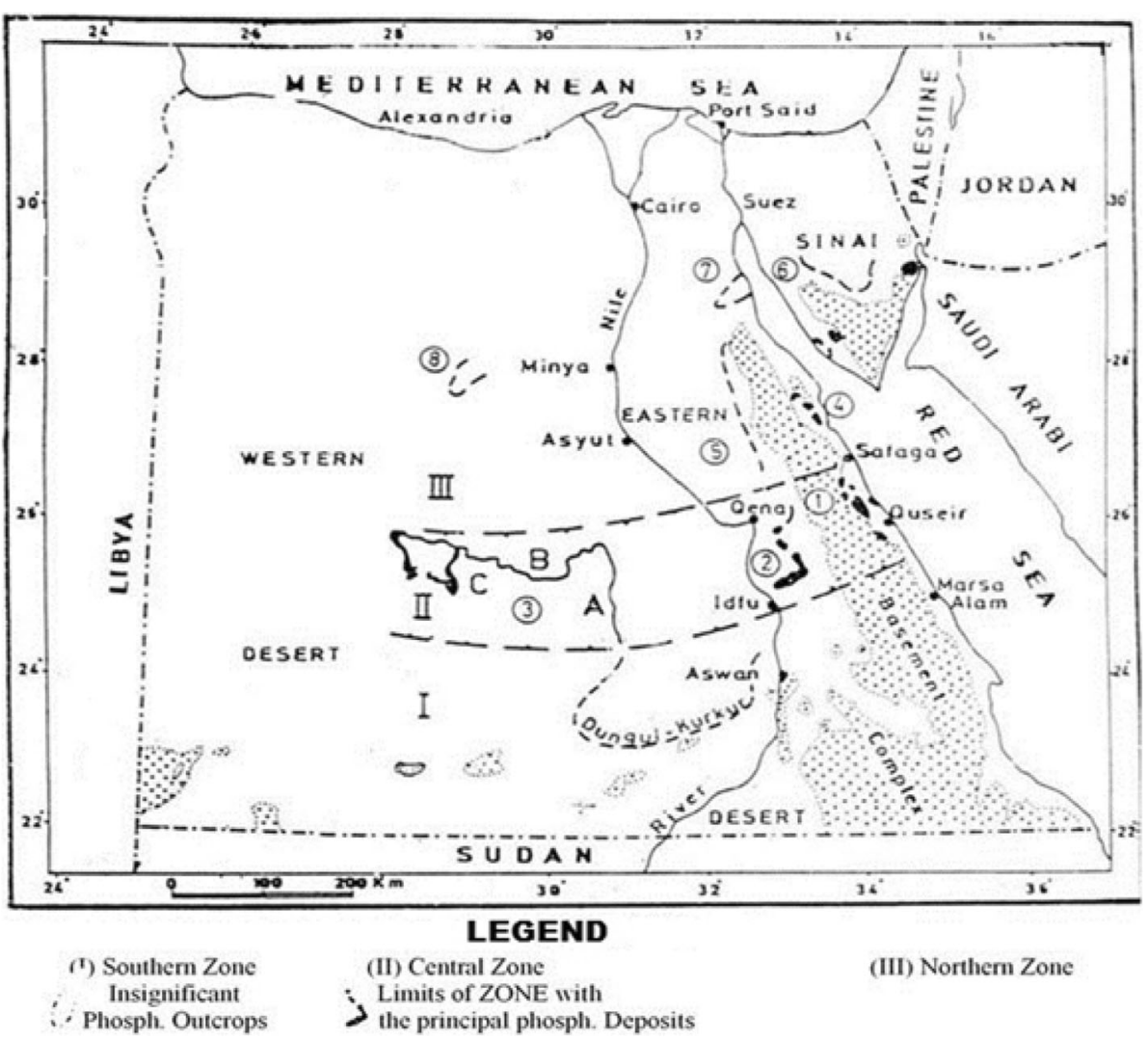

Fig. 1 Distribution of phosphate deposits in Egypt

$\mathrm{P}_{2} \mathrm{O}_{5}$. The reserves of phosphate rock from the Red Sea area are nearly exhausted. ENMC lists $1.6 \mathrm{mmt}$ and a minimum of $27 \% \mathrm{P}_{2} \mathrm{O}_{5}$ as reserves. The content from the Red Sea has been marketed for direct application. There are seven mines of highest quality rock phosphate in south Egypt with the capacity to produce $1,000,000 \mathrm{mt} /$ year. Current loading capacity stands at 8000 tons/day. In Egypt, phosphate ore reserves are present in three main localities, namely Nile Valley, New Valley in Western Desert, and the Eastern Desert along the Red Sea Coast (Nagui et al. 2014). Currently, newly discovered phosphate ores are being mined from Nile Valley areas mainly for exportation and partially for local production of fertilizers. However, in exporting such ores, the mining companies export only the coarse fractions of the run of mine ores of high grade (over 30\% $\left.\mathrm{P}_{2} \mathrm{O}_{5}\right)$ not the fine fractions of low grade $(\sim 18-22 \%$ $\left.\mathrm{P}_{2} \mathrm{O}_{5}\right)$. This is because such fine fractions contain different gangue minerals such as calcite and silica. This paper aims at studying the amenability of upgrading such rejected fine fractions of Nile Valley areas through application of froth flotation process. Such flotation technique is investigated to separate the associated gangues (silica and calcite) from the fine fractions of phosphate ores. The different operating conditions affecting the efficiency of separation of phosphate mineral from its associated gangues are studied. These parameters, among others, are collector dosage, depressant dose, and $\mathrm{pH}$. At the optimum conditions of flotation, a phospho-concentrate of $\mathrm{P} 2 \mathrm{O} 5$ of about $29.5 \%$ and $7.6 \%$ A.I. is obtained from a feed sample containing about $21.13 \% \mathrm{P}_{2} \mathrm{O}_{5}$ and $19 \%$ A.I.

About $95 \%$ of the phosphates produced are consumed in the agricultural sector as fertilizers and animal feedstocks (Elmaadawy et al. 2015). Most of the balance is converted into phosphoric acid and elemental phosphorus which are the raw materials for manufacturing various phosphate compounds. The world's annual phosphate production in 2012 is around 217 million tons, and the global reserves amount to 67 billion tons. With increasing population, researchers estimate the existing phosphate reserves cover the world needs of phosphates for more than 100 years to come. Egypt has about $4 \%$ of the world's phosphate reserves (2.78 billion tons) and produces about $3 \%$ of the world's phosphate production (about 6 million ton/year). The phosphate deposits in Egypt lie between latitudes $23^{\circ} 10^{\prime}$ and $30^{\circ} 50^{\prime} \mathrm{N}$, whereas the payable zone lies between latitudes $24^{\circ} 30^{\prime}$ and $26^{\circ} 50^{\prime} \mathrm{N}$. They extend longitudinally from the Red Sea Coast to El Dakhla Oases. Geologically, the 
economic phosphate beds belong to the central facial zone of the Upper Senonian age deposits. They cover the Red Sea Coast, Nile Valley, and Western Desert. The $\mathrm{P}_{2} \mathrm{O}_{5}$ content ranges from 20 to $32 \%$.

The reserves and production rates in the various phosphate ore localities in Egypt are summarized in Table 1. The total proved reserves of the phosphate ore in Egypt amounts to 2.780 billion tons. The average production rate varies from 3.0 to 5.0 million tons per year. However, the USGS Mineral Commodity Summary for phosphate reported that the phosphate production in Egypt went up to 6.24 million ton in the years 2010, 2011, and 2012 (Jasinski 2014). This jump could be attributed to a sudden increase of production rate that took place at Abu Tartur lately. It jumped from 500,000 ton to 2 million ton from the oxidized type at the scarf of the plateau. Table 2 showed the chemical composition of phosphate rock in the main points that could be deduced as follows: (a) all the used phosphate rocks can be categorized as low-grade phosphate ores $\left(\mathrm{P}_{2} \mathrm{O}_{5}\right.$ ranges between 19 and 27\%) and (b) the studied phosphate rock samples are remarked by different contents of their radioactive elements (Salib 2006).

\section{Biological solubilization of phosphate rock Partial acidulation}

The phosphate rock dissolution can be carried out through two main routes, namely partial acidulation and complete acidulation. Both routes could be performed by organic or mineral acids. The partial dissolution of phosphate rocks is based on the acidulation of one third of the phosphate material by acids to produce soluble monocalcium phosphate which is known in the fertilizer industry as superphosphate. The studied phosphate rock samples are remarked by different contents of their radioactive elements. However, in the complete acidulation, the sulphuric acid is advantageous since it is the only acid which forms gypsum (phosphogypsum) as an insoluble precipitate $\left(\mathrm{CaSO}_{4} \cdot 2 \mathrm{H}_{2} \mathrm{O}\right)$. Consequently, phosphoric acid can be separated from the slurry directly by filtration. The effect of phosphate rock acidulation with acetic acid (RPAA), citric acid (RPCA), and PR added with composted orange peel (RPOM) compared to triple superphosphate (TSP) for corn plants is studied by (El Gala and Bordeny 2004). They concluded that acidulation of phosphate rock is important for increasing the available phosphorus from phosphate rock and improving crop yield from the P-deficient soil.

The phosphate rock was simultaneously solubilized by the organic acids (Vassileva et al. 2000). Indeed, the phosphorous solubilization depends on the mode of biocatalyst applications (free or encapsulated cells) and the initial concentration of phosphate rock in the cultivated medium. Ghosal and Chakraborty (2012) examined the solubility of four sources of phosphatic fertilizers namely, triple superphosphate (TSP; $21.75 \%$ P), partially acidulated phosphate rock (PAPR; $12.97 \%$ P), Morocco phosphate rock (MORP; 14.87\% P), and Mussoorie phosphate rock (MRP; $8.12 \% \mathrm{P}$ ) by six different extractants, namely $2 \%$ citric acid, $0.002 \mathrm{~N}$ hydrochloric acid, $\mathrm{N}$-Ammonium citrate, Bray-2P extractant, Olsen's extractant, and Morgan's reagent under seven periods of incubation $(1,2,3,7,10$, 15 , and 30 days), with and without soil. The partially acidulated source released $\mathrm{P}$ higher than phosphate rock but lower than triple superphosphate after (1-3 days) incubation (1.31-1.34\% with soil, $0.46 \%$ without soil) with an increase in the later periods (seventh day) $(1.27-1.92 \%$ with soil, $0.55-0.66 \%$ without soil). The phosphate rocks released maximum phosphorus after the seventh day of the incubation period. Among the different solvents used, maximum phosphorus released was observed by $2 \%$ citric acid and Olsen's extractants.

\section{Elemental sulphur addition}

The assays to produce phosphorous biofertilizers from phosphate rock (PR), applying sulphur at different rates

Table 1 Reserves and annual production rates of phosphate ore in Egypt

\begin{tabular}{|c|c|c|c|c|c|c|}
\hline Area & Location & Reserves, $\mathrm{M}$ tons & $\begin{array}{l}\text { Produc., } \\
1000 \text { ton/year }\end{array}$ & $\begin{array}{l}\text { Average assay, } \\
\mathrm{P}_{2} \mathrm{O}_{5}(\%)\end{array}$ & Associated constituents & Mining** status \\
\hline \multirow{3}{*}{$\begin{array}{l}\text { Red Sea } \\
\text { Coast }\end{array}$} & Safaga area & 30 & - & $18-28$ & \multirow{3}{*}{$\begin{array}{l}\mathrm{SiO}_{2} \text {, clays, carbonates }(\mathrm{Ca} \text {, } \\
\mathrm{Mg})\end{array}$} & \multirow[t]{3}{*}{ U } \\
\hline & Hamraween & 50 & - & $18-28$ & & \\
\hline & Qussier & 20 & - & $18-28$ & & \\
\hline \multirow[t]{3}{*}{ Nile Valley } & E. Sebaiya & 80 & 2000 & $24-31$ & \multirow[t]{3}{*}{$\mathrm{SiO}$, clays, carbonates (Ca) } & \multirow{3}{*}{$\begin{array}{l}S+U \text { mainly } \\
\text { surface }\end{array}$} \\
\hline & W.Sebaiya & 100 & 900 & $20-28$ & & \\
\hline & Quena area & 1500 & - & $15-24$ & & \\
\hline New Valley & Abu Tartur & $\begin{array}{l}1000^{*} \text { out of them } 124 \mathrm{M} \text { tons } \\
\text { oxidized ore }\end{array}$ & Up to 2100 & $22-26$ & $\begin{array}{l}\mathrm{SiO}_{2} \text {, clays, dolomote, } \\
\text { gypsum, pyrite }\end{array}$ & $\begin{array}{l}S+U \text { majority } \\
\text { surface }\end{array}$ \\
\hline \multicolumn{2}{|l|}{ Total } & 2780 & \multicolumn{3}{|l|}{5000} & \\
\hline
\end{tabular}

$U$ underground mining, $S$ surface mining

*These reserves are the verified reserves at Abu Tartur. The probable and possible phosphate reserves at Abu Tartur location are almost ten times this amount 
Table 2 Composition of phosphate rock in Egypt

\begin{tabular}{llll}
\hline Oxide (\%) & El Sebaiya PR & Safaga PR & Abu Tartur PR \\
\hline $\mathrm{P}_{2} \mathrm{O}_{5}$ & 24.9 & 19.4 & 27.3 \\
$\mathrm{CaO}$ & 43.5 & 43.9 & 40.2 \\
$\mathrm{Fe}_{2} \mathrm{O}_{3}$ & 2.27 & 1.2 & 2.93 \\
$\mathrm{SiO}_{2}$ & 12.2 & 3.71 & 6.13 \\
$\mathrm{Al}_{2} \mathrm{O}_{3}$ & 1.83 & 2.21 & 1.7 \\
$\mathrm{Na}_{2} \mathrm{O}$ & 1.62 & 1.73 & 0.72 \\
$\mathrm{~K}_{2} \mathrm{O}$ & 0.12 & 0.16 & 0.13 \\
$\mathrm{MgO}^{-}$ & 1.52 & 5.3 & 1.26 \\
$\mathrm{Cl}^{-}$ & 0.55 & 0.45 & 0.17 \\
$\mathrm{CO}_{2}^{-}$ & 8.66 & 17 & 7.25 \\
$\mathrm{SO}_{3}^{-}$ & 3.73 & 1.35 & 8.75 \\
$\mathrm{~F}^{-}$ & 1.16 & 1.21 & 3.0 \\
\hline
\end{tabular}

of 10,15 , and $20 \%$, and inoculation with Thiobacillus were studied by Besharati et al. (2007). Higher rates of measured parameters were obtained from biofertilizers with sulphur and Thiobacillus (BioF) with triple superphosphate (TSP). Biofertilizers with sulphur and Thiobacillus (BioF) + TSP increased plant parameters significantly compared with control or phosphate rock.

To evaluate the best combination of phosphate rock (RP), sulphur (S), organic manure, and phosphate-dissolving bacteria (PDB) inoculation to enhance the availability of phosphorus from phosphate rock and their effects on yield of broad bean plants (Khalil 2013). Results concluded that sulphur application or PDB inoculation with RP had a significant effect on broad bean yield and its quality. Application of RP and different soil amendments individually or together increased nitrogen, phosphorus, and potassium contents in straw and seeds of broad bean. The highest nutrient contents were found when the plants are fertilized with a mixture of RP and different soil amendments. Results showed the significant role of organic matter, sulphur, and PDB for releasing available phosphorus from phosphate rocks.

\section{Compost addition}

The relative residues effectiveness (RRE) of superphosphate was greater than the phosphate rock (Abdel-Hamid et al. 2003). Wheat was the most effective in obtaining P from the residues of phosphate rock due to its low external P requirements. The RRE was $0.11-0.52$ for wheat and 0.02-0.24 for sesame plants. Values of RRE based on plant P content differ from those based on dry matter yield. The results of this work provided the recommendation that it could be possible to mix phosphate rock deposit with organic manures to be applied in soils as a slow P release fertilizers. The release of phosphorus from phosphate rock through composting using organic materials and its effect on corn growth were studied by Badr and Taalab (2005). The concentration of total $\mathrm{P}$ was significantly enhanced in the final product with all treatments as organic materials decreased during composting compared to control where no P was added. Phosphorus from phosphate rock was solubilized and transformed into available forms during composting.

Akande et al. (2011) studied the amendments of Ogun phosphate rock (ORP) with an organic waste and urea and its effects on growth and seed yield of two varieties of kenaf (Cuba 108 and Tainung 1). The treatments used were ORP + cow dung, ORP + compost, ORP + poultry manure, and ORP + Urea, and they were assessed and compared with a no-fertilizer control treatment. Results showed that $\mathrm{P}$ application significantly increased kenaf plant height and seed yield. NPK-treated plants were significantly taller than the unfertilized plants. However, plants treated with amended ORP had comparable heights among the three organic sources and with NPK fertilization. NPK fertilization produces the highest seed yields with the two studied varieties. ORP application performed similar effect as NPK 20-10-10 when applied with organic manures and urea for kenaf production.

The effect of reactive phosphate rock for maize on an ultisol in Pleihari, South Kalimantan province, was reported by Husnain et al. (2014). They conducted a field experiment to evaluate the direct application of reactive phosphate rock (RPR) for maize and its combination with manure and agronomic effectiveness. Reactive phosphate rock improved soil fertility and maize crop productivity. Moroccan phosphate rocks contained the highest citric acid extractable $\mathrm{P}_{2} \mathrm{O}_{5}$ as compared to other phosphate rock tested and were the most effective in increasing maize production (Husnain et al. 2014).

\section{Microorganisms \\ Fungi}

Filamentous fungi are widely used as producers of organic acids, and particularly, some Aspergillus and Penicillium species have been applied directly into the soil in order to solubilize the phosphate rock. Inoculation of phosphate-solubilizing fungi and mycrohizal fungi improves the physicochemical, biochemical, and biological properties of PR-amended soil. Penicillium aurantiogriseum and Pseudomonas spp. have high abilities to solubilize inorganic phosphates (Santi et al. 2000). The interaction between microorganisms that release organic acids and other products onto the surface of minerals which may liberate ions from their surface layers was reported by Reyes et al. (2006). In this case, phosphate rock dissolution by microorganisms directly affects the fertility of soils. Hellal et al. (2013) produced a compost from rice straw enriched with phosphate rock and inoculated with Aspergillus niger, Trichoderma viride, and or 
farmyard manure. The resulting composts were evaluated as organic phosphate fertilizers for maize plants in pot experiments. The results showed that the higher amount of soluble phosphorus was attained from composts inoculated with Aspergillus niger plus Trichoderma viride with or without farmyard manure. The composted rice straw produced was much better than the superphosphate in maintaining the growing maize with available phosphorous.

\section{Bacteria}

The growth kinetics of the bacterium Thiobacillus thiooxidans and its metabolic acidic solution which was applied to phosphate rock bioleaching was studied by Maochun et al. (2002). The diluted microbiological acid solutions produced by HSS were used to dissolve fluroapatite ore. The digestion conversions of phosphorous ranged from 24 to $100 \%$. Fluorine ion contained in fluroapatite ore showed a significant effect on the biological activity of Thiobacillus thiooxidans. The bacteria, fungi, and yeast can play important roles in phosphorus solubilization showed by Zhong and Huang (2005). Strains of phosphorous bacteria P17 (Bacillus megathirum) could easily dissolve phosphorus from phosphate rock powder from Huangmailing of Hubei province. Results showed that different strains of P-dissolving microbes can accelerate solubilization of phosphors to a varying extent; this reveals that different chemical bonds have different effects on solubilization of phosphates and phosphate rock powder valid in solubility. Acids, acid phosphates, and alkaline phosphates have synergic effects on phosphate dissolution. Hameeda et al. (2008) pointed out that five bacterial strains with phosphate-solubilizing ability and other plant growthpromoting traits increased the plant's biomass (20-40\%). Glass house and field experiments were conducted using two efficient strains Serratia marcescens EB67 and Pseudomonas sp. CDB35. Population of EB67 and CDB35 were traced back from the rhizosphere of maize on buffered phosphate rock medium, and both strains survived up to 96 days after sowing.

\section{Acetinomycetes}

The presence of the acetinomycete strains in the soil supplemented with phosphate rock significantly promoted the growth of the wheat plants (Hamdali et al. 2008). Also, this study demonstrated that Micromono sporaaurantica-related strains isolated from Morocco phosphate mines in association with pulverized phosphate rock could constitute a novel and non-polluting biofertilizer/biocontrol product useful for the development of sustainable agriculture. El Tarabily et al. (2008) studied the determination of the potential of non-Streptomycete acetinomycetes to solubilize insoluble phosphate in soil and to promote plant growth.

\section{Mycorrhiza}

Enzyme activities increase in soils amended with microorganisms. Moreover, these amendments have been shown to be highly efficient in association with arbuscular mycorrhiza (AM). Also, soil microorganisms can affect the AM formation and function (Alguacil et al. 2008). Particularly, the so-called mycorrhiza helper bacteria are known to stimulate mycelia growth of mycorrhizal fungi or to enhance mycorrhizal formation. In Table 3, it can be concluded that Red Sea phosphate rock sediments can be used in combination with compost of plant residues or chicken manure accompanied with certain microorganisms as a phosphorus fertilizer to improve the phosphorus status and rare earth elements (REEs) in the clay soil and consequently the $\mathrm{P}$ availability and uptake by wheat plants (HakamMahdy 2011).

The effect of Oroba and Sebaiea PR application on seed yield and phosphorus uptake by soybean plants is presented in Table 4. They concluded that phosphate rock inoculated with bacteria and mycrrohizae proved to be the appropriate technology to use PR and organic waste for continuous crop production as well as supporting healthier environment (Rasha 2014).

\section{Phosphate rock for direct application in agriculture}

The direct application of phosphate rock sources as fertilizers has several advantages, e.g., phosphate rock are natural minerals that require minimum metallurgical processing. Being natural compounds, it can be used in organic agriculture. Direct application enables the utilization of phosphate rock sources that cannot be utilized for industrial purposes in the manufacture of water-soluble phosphate fertilizers and phosphoric acid. Phosphate rock is suitable for direct application and can be more efficient than water-soluble phosphate fertilizers in terms of phosphorus recovery by plants under such conditions. Based on the unit cost of phosphorus, natural or indigenous phosphate rock is usually cheap. Due to their extremely variable and complex chemical composition, phosphate rock is a source of several nutrients other than P. However, it has some limitations as observed by Zapata and Roy (2004).

- The effectiveness of some medium-to-low-reactive phosphate rock needs to be enhanced by biological and physico-chemical processes.

- A standard characterization of phosphate rock is required as for providing them suitable application in soil, and cropping systems are suitable.

- The low grade of some phosphate rocks compared with higher grade commercial phosphate fertilizers 
Table 3 Residual of $\mathrm{P}_{2} \mathrm{O}_{5}$ and REEs in clay soil after harvesting of wheat

\begin{tabular}{|c|c|c|c|c|}
\hline \multirow[t]{2}{*}{ Treatments } & \multicolumn{2}{|c|}{ Abu Tartur PR } & \multicolumn{2}{|c|}{ Red Sea PR } \\
\hline & $\mathrm{P}_{2} \mathrm{O}_{5}(\%)$ & REEs (\%) & $\mathrm{P}_{2} \mathrm{O}_{5}(\%)$ & REEs (\%) \\
\hline Phosphate rock (PR) & 5.44 & nd & 5.44 & nd \\
\hline $\mathrm{PR}+$ mycrrohizae $(\mathrm{M})$ & 5.75 & 2.7 & 5.75 & 15.3 \\
\hline $\mathrm{PR}+$ Bacillus licheniformis (CLS1) & 4.03 & 2 & 1.81 & 10.9 \\
\hline PR + Bacillus amyloliquefaciens (CS1) & 5.75 & 3.2 & 5.13 & 10.3 \\
\hline $\mathrm{PR}+$ Bacillus licheniformis $+\mathrm{M}$ & 4.37 & 3.4 & 5.38 & 14.9 \\
\hline $\mathrm{PR}+$ Bacillus amyloliquefaciens $+\mathrm{M}$ & 10.58 & 3.2 & 5.38 & 13.7 \\
\hline PR + Compost & 7.14 & 9.1 & 7.13 & 14.7 \\
\hline PR + Compost + Mycrrohizae & 10.58 & 3.7 & 10.58 & 16.3 \\
\hline PR + Compost + Bacillus licheniformis & 5.14 & 2.2 & 2.78 & 16.6 \\
\hline $\mathrm{PR}+$ Compost $+\mathrm{CS} 1$ & 7.82 & 4.2 & 6.42 & 12.6 \\
\hline $\mathrm{PR}+$ Compost $+\mathrm{CLS1}+\mathrm{M}$ & 5.41 & 3.7 & 5.78 & 18.3 \\
\hline $\mathrm{PR}++$ Compost $+\mathrm{CS} 1+\mathrm{M}$ & 11.17 & 3.4 & 6.42 & 17.6 \\
\hline $\mathrm{PR}+$ chicken manure $(\mathrm{Ch})$ & 7.83 & 2.5 & 7.82 & 16 \\
\hline$P R+(C h)+M$ & 16.45 & 4.8 & 16.45 & 19.2 \\
\hline $\mathrm{PR}+(\mathrm{Ch})+\mathrm{CLS1}$ & 10.58 & 3.4 & 8.19 & 22.3 \\
\hline $\mathrm{PR}+(\mathrm{Ch})+\mathrm{CS} 1$ & 16.45 & 5.1 & 8.12 & 14.3 \\
\hline$P R+(C h)+C L S 1+M$ & 13 & 5.2 & 12.41 & 25.7 \\
\hline$P R+(C h)+C S 1+M$ & 14.73 & 4.3 & 8.27 & 23.3 \\
\hline
\end{tabular}

makes them more expensive regarding their application.

- Sedimentary phosphate rocks show a very complex structure as a result of their different origin in nature and even within a particular geological deposit. Thus, they have extremely variable chemical constituents and may contain elements such as heavy metals and even radionuclides that upon dissolution of the phosphate rock in the soil may be harmful at some concentrations.

Table 4 Effect of PR with mycrohizae on soybean seed yield and $P$ uptake

\begin{tabular}{|c|c|c|c|c|}
\hline \multirow[t]{3}{*}{ Treatments } & \multirow{2}{*}{\multicolumn{2}{|c|}{$\frac{\text { Seed yield, } \mathrm{kg} / \mathrm{fed}}{\text { Mycorrhizae }}$}} & \multirow{2}{*}{\multicolumn{2}{|c|}{$\frac{\text { P uptake, mg/plant }}{\text { Mycorrhizae }}$}} \\
\hline & & & & \\
\hline & Without & With & Without & With \\
\hline Single superphosphate & 1024 & 1296 & 402.5 & 1004.0 \\
\hline Oroba phosphate rock (OPR) & 317 & 416 & 29.7 & 89.2 \\
\hline OPR 20\% & 1024 & 1354 & 395.6 & 819.1 \\
\hline OPR $20 \%+P S B$ & 1156 & 1537 & 586.1 & 2309 \\
\hline Sebeia phosphate rock (SPR) & 324 & 449 & 45.3 & 110.4 \\
\hline SPR 20\% & 1102 & 1325 & 480 & 1144 \\
\hline SPR $20 \%+$ PSB & 1296 & 1600 & 618.3 & 2462 \\
\hline
\end{tabular}

OPR 20\%: $20 \mathrm{~kg}$ OPR + $10 \mathrm{~kg}$ chicken manure + $70 \mathrm{~kg}$ peanut shell; SPR 20\%: $20 \mathrm{~kg} \mathrm{SPR}+10 \mathrm{~kg}$ chicken manure $+70 \mathrm{~kg}$ peanut shell $P S B$ phosphate-solubilizing bacteria
The reactivity of these phosphate rocks was determined using common extractants (formic acid, citric acid, and neutral ammonium citrate) and classified on the basis of International Fertilizer Development Center-proposed classification method for direct application. The reactivity of Iranian phosphate rocks was quite low compared to Gafsa phosphate rock. The long-term dissolution kinetics of phosphate rocks determined with formic acid and citric acid showed slow reaction initially $(0-20 \mathrm{~min})$ because of the presence of free calcium carbonate, but after that, the reaction rate increased surpassing Gafsa phosphate rock (Abdollatif et al. 2009).

\section{Factors affecting agronomic performance of phosphate rocks \\ Rock factors \\ Reactivity of $P R$}

Phosphate rock reactivity is a measure of the rate of dissolution of phosphate rocks under standard laboratory conditions or in a given soil and under given field conditions (Rajan et al. 1996). The dissolution rate of phosphate rocks is mostly affected by soil properties and plant characters. The chemical composition and particle size of phosphate rocks control their reactivity. Sedimentary origin phosphate rocks are generally most reactive and suitable for direct application. Calcium carbonate is the most abundant accessory mineral in 
phosphate rocks. As calcium carbonate is more soluble than the most chemically reactive phosphate mineral, its dissolution increases the calcium content and $\mathrm{pH}$ at the phosphate mineral surface. So, calcium carbonate can reduce the rate of phosphate rock dissolution in some soils.

\section{Rate of phosphate rocks application}

The rate of phosphate rock application needs to be based on the soil P status as indicated by soil test (Perrott and Wise 2000), the expected rate of dissolution of phosphate rock, and its availability to plants. The soil test technique to be utilized would rely upon whether the phosphate manure connected already was a water-dissolvable frame or a phosphate rock. Some broad rule is that phosphate rock application is probably going to be gainful in soils of medium phosphorus status. In soils of low phosphorus status, there are two decisions: (i) convey the richness level to medium phosphorus status by applying water-dissolvable composts and take after this by the use of phosphate rock and (ii) fuse substantial utilizations of phosphate rocks (500-1000 kg/ha) trailed by a general phosphorus application. Table 5 shows the phosphorous solubilization efficiency was highest in the fourth week for all the applied phosphate rocks, except for El Sebaiya PR in the calcareous soil, and then it decreased in the sixth week. On the other hand, phosphorous solubilization efficiency of all the sources of the phosphate rock samples is applied to the sand and calcareous soils attained; generally, its highest values in the second week thereafter tended to decrease with time up to the sixth week (HakamMahdy 2011).

\section{Timing of phosphate rock application}

In acidic soils $(\mathrm{pH}>5.5)$ with a high phosphate retention capacity, the incorporation of phosphate rock close to planting time is recommended in order to minimize the conversion of dissolved $\mathrm{P}$ to plant "unavailable" forms. Be that as it may, in less corrosive soils $(\mathrm{pH}$ of around 5.5-6) with a low phosphate maintenance limit, joining of phosphate rock 4-8 weeks in front of planting is favored. This permits time for some disintegration of phosphate rock and its ensuing accessibility to plants. Lab tests have demonstrated that it might take four 2 months for phosphate rocks to achieve their greatest dissolvability. The use of phosphate rock for flooded rice requires special attention because soil $\mathrm{pH}$ generally increases upon flooding. For this reason, it is advisable to apply PR to the soil about 2 weeks before flooding (Zapata and Roy 2004).

\section{Soil factors}

Soil properties that influence the dissolution of apatite minerals in the phosphate rocks are $\mathrm{pH}, \mathrm{CEC}, \mathrm{Ca}$
Table 5 Effect of PR rates on P solubilization efficiency after four weeks incubation

\begin{tabular}{|c|c|c|c|c|}
\hline Rate, g/100 g soil & Sebaiya PR & Red Sea PR & Abu Tartur PR & Triple SP \\
\hline & Clay soil & & & \\
\hline 0.05 & 17 & 11.2 & 13.2 & 13.1 \\
\hline 0.1 & 13.6 & 13 & 15.5 & 14.1 \\
\hline 0.2 & 9.18 & 16.4 & 16.6 & 25.7 \\
\hline \multirow[t]{2}{*}{0.3} & 13.5 & 14.1 & 26.2 & 12.3 \\
\hline & \multicolumn{4}{|c|}{ Calcareous soil } \\
\hline 0.05 & 6 & 12.3 & 6.7 & 12.3 \\
\hline 0.1 & 12.4 & 3.6 & 7.2 & 10.1 \\
\hline 0.2 & 14.1 & 4 & 10.2 & 14.1 \\
\hline \multirow[t]{2}{*}{0.3} & 11.8 & 7.5 & 8.5 & 24 \\
\hline & \multicolumn{4}{|l|}{ Sandy soil } \\
\hline 0.05 & 30.8 & 29.8 & 31.7 & 41 \\
\hline 0.1 & 32.5 & 23.6 & 27 & 44.2 \\
\hline 0.2 & 37 & 44.5 & 49.6 & 76.3 \\
\hline 0.3 & 25.4 & 27 & 37.9 & 28 \\
\hline
\end{tabular}

concentration, $\mathrm{P}$ concentration, $\mathrm{P}$ sorption capacity, and organic matter content. The driving and "pushing" force for the dissolution of apatites is the neutralizing reaction between proton $\left(\mathrm{H}^{+}\right)$ion concentrations and the apatites in PRs. The response is driven from left to ideal by expanding the $\mathrm{H}+$ particle focuses in the dirt. Soil $\mathrm{P}$ sorption limits additionally impact the disintegration of PR. High P-sorbing soils, for example, oxisols and ultisols, upgrade the disintegration of PRs by lessening the $P$ focus in the quick surroundings of the PR. Slow-release P desorption from these soils might become important in the long term, "turning a liability into an asset" (Sanchez and Leaky 1997). The impact of organic matter on the disintegration of PR is identified with the development of $\mathrm{Ca}$ and natural issue edifices. By lessening $\mathrm{Ca}$ action in the arrangement (Ca sink), the phosphate shake disintegration will be expanded. The higher organic matter content in soil, the better the disintegration of the phosphate rock (Van Straaten 2002).

\section{Soil acidity}

The PR dissolution diminishes with increasing $\mathrm{pH}$ up to 5.5 , but the decline is more rapid above this $\mathrm{pH}$ level. When considering a large number of soils, titratable acidity may be a better indicator of PR dissolution. The comparative effects of forage species on rhizosphere acidification and solubilization of phosphate rocks of different reactivity was studied by (Perez et al. 2007). Dissolution of phosphate rocks in soils requires an adequate supply of acid $\left(\mathrm{H}^{+}\right)$and the removal of the dissolved products [calcium $\left(\mathrm{Ca}^{2+}\right)$ and dihydrogen phosphate $\left.\left(\mathrm{H}_{2} \mathrm{PO}_{4}\right)\right]$. Plant roots may excrete $\mathrm{H}^{+}$or $\mathrm{OH}^{-}$in 
quantities that are stiochiometrically equal to excess cation or anion uptake in order to maintain internal electro neutrality. Extrusion of $\mathrm{H}^{+}$or $\mathrm{OH}^{-}$may affect rhizosphere $\mathrm{pH}$ and $\mathrm{PR}$ dissolution. Nitrate and sulfate $\left(\mathrm{SO}_{4}{ }^{2}\right.$ $\left.{ }^{-}\right)$reduction in Brachiaria root cells may have generated a significant amount of cytoplasmic hydroxide $\left(\mathrm{OH}^{-}\right.$ which could have increased cytoplasmic $\mathrm{pH}$ and induced synthesis of organic acids and $\mathrm{OH}^{-}$extrusion from roots.

\section{Cation exchange capacity}

The calcium ion is ought to be evacuated or that its content in soil solution be kept up at a lower level than that in the film encompassing the dissolving PR molecule. It is conceivable to accomplish these results if there are satisfactory soil cation trade destinations accessible to retain the Ca particle discharged from the $\mathrm{PR}$, or if $\mathrm{Ca}$ is drained far from the site of PR disintegration. A measure of the cation trade destinations accessible for Ca adsorption is the contrast between the cation trade limit of soils and the interchangeable $\mathrm{Ca}$. Recent ponders propose that high replaceable magnesium $(\mathrm{Mg})$ in soils may upgrade PR disintegration (Vanlauwe et al. 2000). Hypothesis would propose that, as Mg is held by soils more firmly than $\mathrm{Ca}$, the nearness of $\mathrm{Mg}$ on the dirt trade locales can piece the adsorption of Ca discharged on disintegration of PR and in this way encourage its expulsion from the soil manure framework. This will improved PR disintegration. In soils with low $\mathrm{pH}$ (under 5.5), the interchangeable $\mathrm{Ca}$ and $\mathrm{Mg}$ will constantly be low base saturation. and consequently, there will be low solution content of these ions.

\section{Soil organic matter}

The soil property that increases PR dissolution and its availability to plants is soil organic matter. This seems to arise from (i) the high cation exchange capacity of organic matter, (ii) the formation of $\mathrm{Ca}$ organic matter complexes, and (iii) organic acids dissolving PR and blocking soil $\mathrm{P}$ sorption sites. At the point when arable crops are harvested, an expansive extent of the root residues and at times some portion of the over the ground parcels are abandoned in soil. The deterioration of plant buildups in soil brings about the creation of various natural acids, for example, oxalic, citrus, and tartaric acids. These acids can be relied upon to break up PR by providing the hydrogen particles expected to neutralize the hydroxyl ions delivered when PR disintegrates and by forming complex with cations, particularly the $\mathrm{Ca}$ from PRs. The natural particles and humus can likewise diminish $\mathrm{P}$ sorption limit of soils by blocking $\mathrm{P}$ sorption destinations and by forming complex with iron and aluminum hydrous oxides, prompting increased $\mathrm{P}$ concentration in solution (Zapata and Roy 2004).

\section{Crop factors}

The ability to use phosphorus from phosphate rock sources differ from crop to crop mainly because the mobilizing capacity of $\mathrm{P}$ from various phosphate rocks varies with crop species (Van Straaten 2002). The best known plants with relatively high P-mobilizing capacities are buckwheat (Fagopyrum esculentum), white sweet clover (Melilotus albus), kale, or rape (Brassica napus), white lupins (Lupinus albus), cabbage (Brassica oleraced), Pigeon pea (Cajanus cajan). Legumes are especially suited for the utilization of PRs. They are compelling in dissolving PR and in engrossing its disintegration items in view of their interest for $\mathrm{Ca}$ and the acidifying impact of nitrogen $(\mathrm{N})$ fixation in the soil close to the root framework (rhizosphere). This effect can be utilized to improve the $\mathrm{P}$ nutrition of a companion crop (intercropping) or that of the subsequent crop in a rotation (Perrott 2001). Some plant species (e.g., rapeseed, lupines, and pigeon pea) have been studied because of their ability to secrete organic acids that result in an enhanced dissolution of PR (Montenegro and Zapata 2002). Reactive PRs may have potential applications even in alkaline soils with organic acid-secreting crops such as rapeseed (canola). The influence of $\mathrm{P}$ source, rate, and frequency on dry matter yield of maize and cowpea grown sequentially in three soil types studied by Akande et al. (2010). Phosphate application significantly enhanced dry matter yields of maize and cowpea. Single superphosphate (SSP) gave a higher total biomass than the phosphate rocks (PR). In the regular application frequency in the first cropping, maize total biomass was increased by single superphosphate from $4.23 \mathrm{~g} /$ plant to $8.20,9.25$, and 9.72 with 20,40 , and $60 \mathrm{~kg} \mathrm{P} / \mathrm{ha}$ while it was increased to $6.78,6.26$, and 6.34 g with OPR but to $6.88,7.60$, and $7.15 \mathrm{~g}$ with CS. Cowpea yield were increased from $2.12 \mathrm{~g} /$ plant to 3.28 , 4.04, and $3.36 \mathrm{~g}$ with single superphosphate to 3.34, 3.27 , and 2.61 with CS and to $2.59,2.78$, and $2.39 \mathrm{~g}$ with OPR.

\section{Climate conditions}

Rainfall is the most important climate factor that influences PR dissolution and its agronomic effectiveness. Increased soil water brought about by rainfall or irrigation increases PR dissolution. The process is influenced by rapid balance of the hydroxyl ions discharged and evacuation of $\mathrm{Ca}$ and other response items from the region nearby PR particles. Satisfactory water supply will energize plant development and $\mathrm{P}$ take-up by plants prompting expanded agronomic adequacy of PRs. For surface-connected PRs, involvement in Australia and New Zealand would demonstrate a yearly precipitation prerequisite of no less than $850 \mathrm{~mm}$ for PRs to be agronomically like water-soluble fertilizers (Hedley and Bolan 
1997). However, the rainfall requirement does depend on soil properties, the overall factor influencing the phosphate rock solubility.

\section{Trace elements in the phosphate rock}

There are many trace elements in the phosphate rock which can be transferred to the phosphoric acid produced from such phosphate ores. These trace elements may be very harmful to plants and animals. An example is $\mathrm{Cr}$ which can be dissolved (about 75\%) through the purification of phosphoric acid. Similarly $50 \%$ of $\mathrm{Zn}$ can be dissolved during the purification process; they can be precipitated later in solid waste samples. About $50 \%$ of $\mathrm{Ni}$ in the phosphate rock was dissolved through manufacture (El Gamal 2007). The Egyptian phosphate deposits are now considered as an important potential resource for uranium and rare earth elements as by-products. The assured phosphate reserves in Egypt are estimated at about 700 million tons while the geological reserves are calculated as about 3000 million tons.

The assay of uranium in the Egyptian phosphate ores is $60 \mathrm{ppm}$; consequently, the phosphate assured reserves are estimated to contain about 40.000 tons uranium at least. Table 6 indicated that the Nile Valley (El Sebaiya) phosphate rock is characterized by its relatively high content of uranium (69 $\mathrm{mg} \mathrm{kg}^{-1}$ ) while the Red Sea phosphate attains $\left(46 \mathrm{mg} \mathrm{kg}^{-1}\right.$ ) and Abu Tartur (oxidized and non-oxidized) phosphate rock samples have lower uranium content (32 and $23 \mathrm{mg} \mathrm{kg}^{-1}$, respectively) (Salib 2006).

Thorium contents of the studied phosphate rock samples are 14, 10, 12, and $11 \mathrm{mg} \mathrm{kg}^{-1}$, and Abu Tartur phosphate rocks are characterized by their high content of rare earth elements (REEs) $\left(736 \mathrm{mg} \mathrm{kg}^{-1}\right)$. The REEs could be extracted through the production of phosphoric acid and fertilizer industries. The phosphate fertilizers collected from Abu Zaabal and Abu Tartur vary widely in their heavy metal and uranium content in

\begin{tabular}{llll}
\multicolumn{4}{l}{ Table 6 Trace elements $\left(\mathrm{mg} \mathrm{kg}^{-1}\right)$ contents of phosphate rock } \\
\hline Sample & El Sebaiya PR & Safaga PR & Abu Tartur PR \\
\hline $\mathrm{U}$ & 69 & 46 & 32 \\
$\mathrm{Th}$ & 14 & 10 & 11 \\
$\mathrm{~V}$ & 368 & 123 & 277 \\
$\mathrm{Cd}$ & 5 & 19 & 9 \\
$\mathrm{~Pb}$ & 10 & 20 & 13 \\
$\mathrm{Cu}$ & 11 & 24 & 21 \\
$\mathrm{Cr}$ & 141 & 14 & 86 \\
$\mathrm{Co}$ & 4 & 6 & 11 \\
$\mathrm{Zn}$ & 133 & 142 & 71 \\
$\mathrm{Sr}$ & 681 & 377 & 34 \\
$\mathrm{Rb}$ & 24 & 35 & 66 \\
\hline
\end{tabular}

phosphate rocks of Egypt used for production of fertilizer (Nabil et al. 2013).

The results indicated that heavy metal content was low in Abu Tartur phosphate compared to imported rock and was below the permissible limits with the exception of lead which was higher in local phosphate deposits than the imported rock samples. Phosphate rock is a source of heavy metal pollution (air, soil, water, food chain, etc.) therefore requires removal from the rock prior to its use for direct application in agriculture.

\section{Conclusion}

Phosphate rocks is relatively slow in releasing soluble P, yet its low price appears to be very attractive as a phosphate fertilizer in comparison with industrial $\mathrm{P}$ fertilizers. In Egypt, the natural phosphate rock is located in Sebaiya (Nile Valley), Safaga (Red Sea), and Abu Tartur (Western Desert). There are specific soil properties that influence the dissolution of apatite minerals in the phosphate rocks. They are $\mathrm{pH}, \mathrm{CEC}, \mathrm{Ca}$ concentration, $\mathrm{P}$ concentration, $\mathrm{P}$ sorption capacity, and organic matter content. It could be argued that phosphate rock inoculated with bacteria and mycorrhiza is proved to be available approach to use PR for persistent crop production. In addition, amendments such as elemental sulphur, compost, organic manure, and plant waste can be applied to improved crop cultivation in Egypt.

\section{Acknowledgements}

This study was supported by Plant Nutrition department, National Research Centre, Egypt.

\section{Funding \\ Not applicable}

Availability of data and materials

The authors agree to use data and materials with refer to the reference.

Authors' contributions

All authors participated in preparing and treating of the experiments and writing of the manuscript. All authors read and approved the final manuscript.

\section{Ethics approval and consent to participate Not applicable \\ Consent for publication \\ The authors are consent for publication this manuscript in the NRC bulletin. \\ Competing interests \\ The authors declare that they have no competing interests.}

\section{Publisher's Note}

Springer Nature remains neutral with regard to jurisdictional claims in published maps and institutional affiliations.

\section{Author details}

'Plant Nutrition Department, National Research Centre, El Buhouth St., Dokki, Cairo 126222, Egypt. ${ }^{2}$ Soil, Water and Environment Research Institute, Agricultural Research Center, El-Gamaa Street, Giza, Egypt. 
Received: 6 November 2018 Accepted: 8 January 2019

\section{Published online: 24 January 2019}

\section{References}

Abdel-Hamid MA, Abdel-Aal SI, Abdel Fattah A (2003) The relative residual effectiveness of superphosphate fertilizer and phosphate rock in Torripsamments. Egypt. J. Soil Sci. 43:35-46

Abdollatif G, Ardalan M, Tehrani MM, Hosseini HM, Karimian N (2009) Solubility test in some phosphate rocks and their potential for direct application in soil. World Applied Sciences Journal 6(2):182-190

Akande MO, Makinde EA, Oluwatoyinbo FI, Adetunji MT (2010) Effects of phosphate rock application on dry matter yield and phosphorus recovery of maize and cowpea grown in sequence. Afr J Environ Sci Technol 4(5):293-303

Akande O, Makinde EA, Aluko OA, Oluwatoyinbo Fl, Adediran JA (2011) Phosphate rock amendment effects on kenaf (Hibiscus cannabinus L.) growth and yield. Tropical and Subtropical Agroecosystems 14(2):559-565

Alguacil MM, Caravaca F, Azcón R, Roldán A (2008) Changes in biological activity of a degraded Mediterranean soil after using microbially-treated dry olive cake as a biosolid amendment and arbuscular mycorrhizal fungi. Eur. J. Soil Bio. 44:347-354

Badr MA, Taalab AS (2005) Release of phosphorus from phosphate rock through composting using organic materials and its effect on corn growth. Bull National Res. Center (Cairo) 30:629-638

Besharati H, Atashnama K, Hatami S (2007) Biosphere as a fertilizer in a calcareous soil with low available phosphorus. African J. of Bio. Tech. 6:1325-1329

Cordell D, Rosemarin A, Schröder JJ, Smit AL (2011) Towards global phosphorus security: a systems framework for phosphorus recovery and reuse options. Chemosphere 84:747-758

El Gala AM, Bordeny MMEL (2004) Studies on possible use of phosphate rock in alkaline soils of Egypt. J. Soil Sci 44:85-95

El Gamal, E. M. F. 2007 Studies on the treatment of solid wastes produced during purification of phosphoric acid at phosphoric acid purification pilot plant, NMA, M.Sc., Faculty of Science, Al-Azhar Univ.

EL Tarabily KA, Nassar AH, Sivasithamparam K (2008) Promotion of growth of bean (Phaseolus vulgaris $\mathrm{L}$.) in a calcareous soil by a phosphate-solubilizing, rhizosphere competent isolate of microspore endolithica. Applied Soil Ecol 39(2):161-171

Elmaadawy KHG, Ezz El Din M, Khalid AM, Abouzeid A-ZM (2015) Ineral Industry in Egypt-Part II non-metallic commodities phosphate rocks. J Mining World Express 4:1-18

Ghosal PK, Chakraborty T (2012) Comparative solubility study of four phosphatic fertilizers in different solvents and the effect of soil. Resources and Environment 2(4):175-179

Rania Abdel HakamMahdy. Studies on solubilization and fertilization by phosphate ores and behavior of their associated elements in some Egyptian soils. Unpublished Ph.D Thesis, Soil Science Department, Faculty of Agriculture, Ain Shams University, Egypt, 2011.

Hamdali H, Hafidi M, Virplle M, Ouhdouch Y (2008) Growth promotion and protection against damming-off of wheat by tow phosphate rock solubilizingacetinomycetes in a P-deficient soil under green house condition. Applied Soil Ecology 40:510-517

Hameeda B, Harini G, Rupela OP, Gopal SP (2008) GrowthPromotion of maize by phosphate solubilizing bacteria isolated from composts and macro fauna. Microb. Res. 2:234-242

Hedley MJ, Bolan NS (1997) Developments in some aspects of reactive phosphate rock research and use in New Zealand. Aust. J. Exp. Agric. 37:861-884

Hellal FA, Nagumo F, Zewainy RM (2013) Influence of phosphocompost application on phosphorus availability and uptake by maize grown in red soil of Ishigaki Island, Japan. Agriculture Sciences 4(2):102-109

Husnain SR, Sutriadi T, Nassir A, Sarwani M (2014) Improvement of soil fertility and crop production through direct application of phosphate rock on maize in Indonesia. Procedia Engineering 83:336-343

Jasinski SM (2014) Phosphate rock. U.S. Geological Survey, Mineral Commodity Summaries, February 2014, 118. https://minerals.usgs.gov/minerals/pubs/ commodity/phosphate_rock/mcs-2014-phosp.pdf.

Khali, A. 2013 A significance of some soil amendments and phosphate issolving bacteria to enhance the availability of phosphate in calcareous soil. ISRN Soil Science, Article ID 438949, 7 pages.

Maochun C, Yongkui Z, Liqou Q, Bin L (2002) Growth kinetics of Thiobacillus strain HSS and its application in bioleaching phosphate ore. Ind. Eng. Chem. Res. 41:1320-1334
Marjolein R, Jong S, Polchar J, Lingemann S (2012) Risks and opportunities in the global phosphate rock market. In: The Hague Centre for Strategic Studies (HCSS)

Montenegro A, Zapata F (2002) Rape genotypic differences in P uptake and utilization from phosphate rocks in an andisol of Chile. Nut. Cyc. Agroecosys 63(1):27-33

Nabil M, Hassan NA, Mansour M, Fayez-Hassan, Sedqy E (2013) Elemental analysis of Egyptian phosphate fertilizer components samples by TGA, DTA and IR methods. IOSR Journal of Environmental Sciences, Toxicol Food Technol 7(3):98-106

Nagui A. Abed-Khalek, Khaled A. Selim, Mohamoud M. Abdallah (2014). Flotation of Egyption newly discovered fine phosphate ore of Nile Valley. Proceedings of the International Conference on Mining, Material and Metallurgical Engineering Prague, Czech Republic, August, 2014,11-12, 150.

Perez MJ, Smyth TJ, Israel SW (2007) Comparative effects of two forage species on rhizosphere acidification and solubilization of phosphate rocks of different reactivity. J. Plant Nut. 30:1421-1439

Perrott K (2001) Direct application of phosphate rocks to pastoral soils phosphate rock reactivity and the influence of soil and climatic factors. In: Rajan SSS, Chien SH (eds) Direct application of phosphate rock and related technology: latest developments and practical experiences. Proc. Int. Meeting, Kuala Lumpur. IFDC, Muscle Shoals

Perrott KW, Wise RG (2000) Determination of residual reactive phosphate rock in soil. Com. Soil Sci. Plant Anal 31:1809-1824

Rajan SS, Watkinson JH, Sinclair AG (1996) Phosphate rocks for direct application to soils. Adv. Agron. 57:77-159

Rasha RA (2014) Effect of compost and bio fertilizers application on phosphorus availability of phosphate rock. Ph.D (Soil Sciences). Cairo University, Egypt

Reyes I, Valery A, Valduz S, Anoun H (2006) Phosphate-solubilizing microorganisms isolated rhizospheric and bulk soils of colonizer plants at an abandoned phosphate rock mine. Plant and Soil 287:69-75

Reyes T, Allsopp M (2012) Phosphorus in agriculture, problems and solutions Greenpeace Research Laboratories, Technical Report (Review)

Salib RM (2006) Phosphate in the Arab world and its potentiality as a secondary source of uranium. Review Article, NMA, Cairo, p 2006

Sanchez PA, Leaky RB (1997) Land-use transformation in Africa: three determinants for balancing food security with natural resource utilization. Eur. J. Agr. 7(1-9)

Santi LP, Goenadi DH, Siswanto IS, Isroi (2000) Solubilization of insoluble phosphates by Aspergillus niger. Menara Perkebunan. 68(2):37-47

Van Kauwenbergh, S (2010) World Phosphate Rock Reserves and Resources Geologist and Principal Scientist Research and Development Division IFDC Fertilizer Outlook and Technology Conference Hosted by The Fertilizer Institute and the Fertilizer Industry Roundtable November 16-18, 2010 Savannah, GA

Van Straaten P (2002) Rocks for Crops: agrominerals of sub-Saharan Africa. ICRAF, Nairobi

Vanlauwe B, Nwoke OC, Diels J, Sanginga N, Carsky RJ, Deckers J, Merckx R (2000) Utilization of phosphate rock by crops on a representative sequence in Northern Guinea savanna zone of Nigeria: response by Mucunapruriens, Lablab purpureus and maize. Soil Bio. Bioch 32:2063-2077

Vassileva M, Azcon R, Barea JM, Vassilev N (2000) Rock phosphate solubilization by free and encapsulated cells of Yarowialipolytica. Process Biochemistry 35:693-697

Zapata F, Roy RN (2004) Phosphate rock for sustainable agriculture. FAO Fertilizer and Plant nutrition Bulletin, Rome

Zhong C, Huang W (2005) Comparison in P solubilizing effect between different P-solubilizing microbes and variation of activities of their phosphates. ActaPedologica-Sinica 42:286-294 